\title{
FAKTOR-FAKTOR YANG MEMPENGARUHI ALIH FUNGSI LAHAN SAWAH DI KABUPATEN ACEH BESAR
}

\author{
(Factors Affecting The Conversion Of Paddy Fields In Kabupaten Aceh Besar )
}

\author{
Raudhatul Husna $^{1}$, Azhar ${ }^{1}$, Edy Marsudi ${ }^{*}$ \\ ${ }^{1}$ Program Studi Agribisnis, Fakultas Pertanian, Universitas Syiah Kuala
}

\begin{abstract}
Abstrak. Alih fungsi lahan atau lazimnya disebut sebagai konversi lahan adalah perubahan fungsi sebagian atau seluruh kawasan lahan dari fungsinya semula (seperti yang direncanakan) menjadi fungsi lain yang membawa dampak negatif terhadap lingkungan dan potensi lahan itu sendiri. Penelitian ini bertujuan untuk mengetahui apakah harga lahan, kepadatan penduduk, produktivitas padi dan jumlah PDRB dapat mempengaruhi alih fungsi lahan sawah di Kabupaten Aceh Besar. Data yang digunakan dalam penelitian ini adalah data sekunder. Data yang dikumpulkan adalah data time series dengan range tahun 2002 sampai 2016. Penelitian ini menggunakan metode analisis regresi linier berganda. hasil penelitian dan pembahasan serta pengujian SPSS menunjukkan bahwa harga lahan, kepadatan penduduk, dan produktivitas padi berpengaruh nyata terhadap alih fungsi lahan sawah di Kabupaten Aceh Besar. sedangkan jumlah PDRB tidak berpengaruh terhadap alih fungsi lahan sawah. Hal ini ditunjukkan oleh koefisien regresi untuk variabel jumlah PDRB sebesar 0,00015. Hasil pengujian statistik menunjukkan nilai t hitung untuk jumlah PDRB sebesar 1,315 dengan nilai signifikan sebesar 0,218. Sedangkan nilai t tabel sebesar 1,782 yang berarti nilai t hitung $<\mathrm{t}$ tabel $(1,315<1,782)$.
\end{abstract}

Kata kunci : Konversi, Lahan Sawah, Aceh besar

\begin{abstract}
Land use change or commonly referred to as land conversion is a change in the function of part or all of the land area from its original function (as planned) into other functions that bring negative impacts to the environment and the potential of the land itself. This study aims to find out whether the price of land, population density, rice productivity and the amount of GRDP can affect the conversion of rice field functions in Aceh Besar District. The data used in this research is secondary data. The data collected is time series data with range of year 2002 until 2016. This research use multiple linier regression analysis method. the results of research and discussion and testing of SPSS showed that land price, population density, and rice productivity significantly affected the conversion of wetland in Aceh Besar district. while the number of GDP does not affect the conversion of wetland. This is indicated by the regression coefficient for the GRDP variable of 0.00015 . The results of statistical tests show the value of $t$ arithmetic for the amount of GRDP by 1.315 with a significant value of 0.218 . While the value of $t$ table of 1.782 which means the value of $\mathrm{t}$ arithmetic $<\mathrm{t}$ table $(1,315<1.782)$.
\end{abstract}

Key words : Conversion, Paddy Field, Aceh Besar

\section{PENDAHULUAN}

Lahan merupakan sumberdaya alam yang penting bagi kelangsungan manusia sebagai tempat kegiatan hidupnya. Kebutuhan ini dari waktu ke waktu semakin meningkat seiring dengan meningkatnya jumlah penduduk dan perkembangan kegiataannya. Sementara itu ruang sebagai wadah kegiatan secara fisik memiliki luasan yang relatif tetap, tidak bertambah. Oleh karena itu, penyeimbangan antara ruang dan kegiatan manusia perlu dipikirkan dengan baik agar tidak terjadi ketimpangan dengan cara konversi lahan pertanian ke pembangunan fisik.

Lahan pertanian mempunyai manfaat yang sangat besar bagi kelangsungan hidup manusia. Manfaat itu tidak hanya dari sektor ekonomi saja, tapi juga sektor lainnya seperti lingkungan, biologis. Oleh sebab itu dengan semakin banyaknya jumlah alih fungsi lahan yang terjadi selama ini akan menimbulkan berbagai permasalahan (Mustopa, 2011).

*corresponding author :edymarsudi@unsyiah.ac.id 
Menurut Irawan, B (2005) menyebutkan bahwa manfaat lahan pertanian dapat dibagi menjadi 2 kategori. Yang pertama use values atau nilai penggunaan yang dapat pula disebut sebagai personal use values. Manfaat ini dihasilkan dari hasil eksploitasi atau kegiatan usahatani yang dilakukan pada sumber daya lahan pertanian. Yang kedua adalah non use values yang dapat pula disebut sebagai intrinsic values atau manfaat bawaan. Yang termasuk kategori ini adalah berbagai manfaat yang tercipta dengan sendirinya walaupun bukan merupakan tujuan dari kegiatan eksploitasi dari pemilik lahan pertanian. Dari teori di atas dapat diketahui bahwa manfaat lahan pertanian sangat besar untuk kelangsungan hidup manusia serta makhluk lainnya. Banyaknya alih fungsi lahan akan mengakibatkan terganggunya keseimbangan alam.

Alih fungsi lahan atau lazimnya disebut sebagai konversi lahan adalah perubahan fungsi sebagian atau seluruh kawasan lahan dari fungsinya semula (seperti yang direncanakan) menjadi fungsi lain yang membawa dampak negatif terhadap lingkungan dan potensi lahan itu sendiri. Alih fungsi lahan pada hakekatnya merupakan hal yang wajar terjadi pada era modern seperti sekarang ini, namun alih fungsi lahan pada kenyataannya membawa banyak masalah karena terjadi diatas lahan pertanian yang masih produktif. Lahan pertanian dapat memberikan banyak manfaat seperti dari segi ekonomi, sosial, dan lingkungan. Namun, jika alih fungsi lahan pertanian produktif dibiarkan saja dan tidak dikendalikan maka sudah tentu akan berdampak negatif bagi masyarakat itu sendiri, mengingat begitu penting dan bermanfaatnya lahan pertanian bagi masyarakat itu sendiri.

Konversi lahan pertanian pada dasarnya terjadi akibat adanya persaingan dalam pemanfaatan lahan antara sektor pertanian dan sektor nonpertanian yang muncul akibat adanya tiga fenomena ekonomi dan sosial, yang banyak muncul dari sektor pertanian ke nonpertanian ialah jalan, perumahan (2 perumnas), rusun tentara, toko, gedung sekolah( SMK Al Mubarkeya). Luas lahan tidak akan pernah bertambah luas akan tetapi permintaan terhadap tanah terus meningkat untuk sektor non pertanian.

Alih fungsi lahan pertanian sebenarnya bukan masalah baru. Sejalan dengan adanya peningkatan jumlah penduduk serta meningkatnya kebutuhan infrastruktur seperti, perumahan, jalan, industri, perkantoran, dan bangunan lain menyebabkan kebutuhan akan lahan meningkat. Selain itu, pertumbuhan ekonomi yang tinggi menyebabkan pertumbuhan yang sangat cepat di beberapa sektor ekonomi. Pertumbuhan tersebut juga membutuhkan lahan yang lebih luas sehingga terjadi peningkatan kebutuhan lahan untuk pembangunan, sementara ketersediaan lahan relatif tetap menyebabkan persaingan dalam pemanfaatan lahan.

Lahan pertanian yang telah dikonversi ke penggunaan lain di luar sektor pertanian akan sangat kecil peluangnya untuk berubah kembali menjadi lahan pertanian. Apabila masalah ini tidak ditangani dan diperhatikan secara khusus, maka akan menambah tingginya angka konversi lahan dan menyempitnya lahan subur pertanian di Kabupaten Aceh Besar yang berdampak langsung terhadap ketahanan pangan. Menurut Martanto, Rachmat (2012) apabila terjadi konversi lahan di suatu lokasi, maka luas lahan yang dikonversi di daerah tersebut akan semakin besar.

Pengurangan luasan sawah akibat konversi lahan mendorong petani untuk mencari sawah di tempat lain. Secara tidak langsung, konversi lahan menyebabkan semakin sulitnya akses petani terhadap lahan. Kondisi ini menggambarkan bahwa petani sangat bergantung terhadap lahan pertanian. Posisi petani semakin terpinggirkan oleh adanya konversi lahan pertanian menjadi perumahan. Dampak lain yang secara tidak langsung dirasakan adalah keberadaan penduduk pendatang yang sebagian besar mengisi 
perumahan membawa pengaruh terhadap kehidupan masyarakat asli. Perilaku hidup yang 'kekotaan' mulai masuk dalam budaya masyarakat desa. Tujuan dari penelitian ini adalah untuk mengetahui apakah harga lahan, kepadatan penduduk, produktivitas padi dan jumlah PDRB dapat mempengaruhi alih fungsi lahan sawah di Kabupaten Aceh Besar.

\section{METODE PENELITIAN}

Penelitian ini dilakukan di Kabupaten Aceh Besar. Pemilihan lokasi penelitian dilakukan secara sengaja (purposive) karena dengan pertimbangan bahwa di Kabupaten Aceh Besar tersebut sangat banyak terjadi pengurangan lahan pertanian sawah yang di sebabkan oleh konversi lahan (lihat tabel 1). Penelitian ini telah dilakukan pada tanggal 08 Januari 2018 hingga 7 Februari 2018 di Kabupaten Aceh Besar dengan mengumpulkan data sekunder dari beberapa instansi yang terkait dengan penelitian ini.

Data yang digunakan dalam penelitian ini adalah data sekunder. Data yang dikumpulkan adalah data time series dengan range tahun 2002 sampai 2016. Data sekunder tersebut diperoleh dari instansi terkait seperti Badan Pusat Statistik (BPS) Provinsi Aceh untuk memperoleh data Alih fungsi lahan, kepadatan penduduk dan data jumlah PDRB. Dinas Pertanian Tanaman Pangan Provinsi Aceh, data yang diperoleh adalah data produktivitas padi. Kanwil Badan Pertanahan Nasional Provinsi Aceh, data yang diperoleh adalah data harga lahan. Sumber lain perolehan data yaitu melalui studi kepustakaan, literature-literature yang terkait dengan penelitian seperti buku, jurnal dan beberapa sumber lainnya yang terkait dengan penelitian.

\section{Model Analisis}

\section{Analisis Regresi Linear Berganda}

Persamaan regresi linear berganda adalah suatu bentuk bentuk persamaan regresi linear antara beberapa variabel bebas dengan satu variabel (terikat). Regresi linear berganda berfungsi untuk mengetahui pengaruh atau hubungan variabel bebas dan variabel terikat. Regresi linear berganda adalah pengujian analisis statistik yang mempelajari pola hubungan antara dua atau lebh variabel yang di formulasikan secara matematis sebagai berikut :

$$
\mathrm{Y}=\mathrm{a}+\mathrm{b}_{1} \mathrm{X}_{1}+\mathrm{b}_{2} \mathrm{X}_{2}+\mathrm{b}_{3} \mathrm{X}_{3}+\mathrm{b}_{4} \mathrm{X}_{4}+\mathrm{e} \ldots . .(\mathrm{Nazir}, 2003)
$$

\section{Dimana :}

$\mathrm{Y}=$ alih fungsi lahan $(\mathrm{Ha} / \mathrm{thn})$

a $\quad=$ Konstanta

b1- b3 = Koefisien variabel

$\mathrm{X}_{1} \quad$ = Harga Lahan $\quad(\mathrm{Rp})$

$\mathrm{X}_{2} \quad=$ Kepadatan Penduduk(jiwa $\left./ \mathrm{km}^{2}\right)$

$\mathrm{X}_{3}=$ Produktivitas Padi $(\mathrm{Ku} / \mathrm{ha})$

$\mathrm{X} 4=$ Jumlah PDRB $\quad(\mathrm{Rp})$

e $\quad$ faktor-faktor yang tidak terobservasi ( error)

Untuk mengetahui besarnya variabel bebas (X) terhadap variabel terikat (Y) secara serempak digunakan uji " $F$ " yaitu :

$$
\mathrm{F}_{\text {(hitung) }}=\frac{\mathrm{R}^{2} / \mathrm{k}}{\left(1-R^{2}\right)(n-k-1)}
$$

Dimana :

$\mathrm{R}^{\mathbf{2}}=$ Koefisien Determinasi 
$\mathrm{k} \quad=$ jumlah variabel

$\mathrm{n} \quad=$ Banyaknya sampel

Kriteria Keputusan :

Ha : Harga lahan, kepadatan penduduk, produktivitas padi dan jumlah PDRB berpengaruh terhadap alih fungsi lahan sawah di Kabupaten Aceh Besar..

$\mathrm{H}_{0} \quad$ : Harga lahan, kepadatan penduduk, produktivitas padi dan jumlah PDRB tidak Dimana : berpengaruh terhadap alih fungsi lahan sawah di Kabupaten Aceh Besar.

$\mathrm{F}_{\mathrm{h}}>\mathrm{F}_{\mathrm{t}}$, pada taraf nyata 0,05 maka terima Ha dan tolak $\mathrm{H}_{0}$

$\mathrm{F}_{\mathrm{h}}<\mathrm{F}_{\mathrm{t}}$, pada taraf nyata 0,05 maka terima $\mathrm{H}_{0}$ dan tolak Ha

Apabila dalam perhitungan menunjukkan bahwa F hitung > F Tabel, maka model tersebut dikatakan signifikan, atau dengan kata lain secara bersama-sama variabel bebas berpengaruh terhadap variabel tak bebas. Begitu juga sebaliknya jika ternyata $F$ hitung < F Tabel maka model tersebut tidak signifiakan, atau dengan kata lain secara bersamasama variabel bebas tidak mempunyai pengaruh terhadap variabel tak bebas.

Sedangkan untuk mengetahui pengaruh masing-masing variabel bebas terhadap variabel terikat secara terpisah, maka digunakan uji t dengan rumus:

$$
\mathrm{t}_{\text {cari }}=\frac{\mathrm{ai}}{\mathrm{SE} a \mathrm{i}}
$$

Dimana $: t=$ uji secara parsial

ai $=$ koefisien regresi

$\mathrm{SE}_{\text {ai }} \quad=$ Standar eror

Dengan ketentuan :

$\mathrm{t}_{\text {(cari) }}>\mathrm{t}_{\text {(tabel) }}$, pada taraf nyata 0,05 maka terima Ha dan tolak $\mathrm{H}_{0}$

$\mathrm{t}_{\text {(cari) }}<\mathrm{t}_{\text {(tabel) }}$, pada taraf nyata 0,05 maka terima $\mathrm{H}_{0}$ dan tolak $\mathrm{Ha}$

apabila dalam perhitungan menunjukkan bahwa t hitung $>$ dari pada t Tabel, maka variabel bebas mempunyai pengaruh yang nyata terhadap variabel bebas, dengan kata lain terima Ha dan tolak Ho. Sebaliknya jika t hitung < dari pada t Tabel maka variabel bebas tidak mempunyai pengaruh yang nyata terhadap variabel bebas, dengan kata lain terima Ho dan tolak Ha.

Model regresi linear berganda disebut sebagai model yang baik apabila model tersebut memenuhi asumsi normalitas data dan terbebas dari asumsi klasik statistik yang meliputi multikolineritas, autokorelasi dan heteroskesdastisitas. Proses uji asumsi klasik dilakukan secara bersamaan dengan proses uji regresi. Pada penelitian ini dilakukan tiga uji asumsi, yaitu normalitas, multikolineritas, dan heteroskesdastisitas (Nugroho,2005).

\section{HASIL DAN PEMBAHASAN}

Uji Faktor-Faktor yang Mempengaruhi Alih Fungsi Lahan Sawah di Kabupaten Aceh Besar

Dari hasil perhitungan statistik dengan menggunakan program SPSS seperti yang terlihat pada tabel diatas, maka diperoleh persamaan regresi linear berganda sebagai berikut : $Y=1005,463+0,478 X_{1}+0,342 X_{2}-97,598 X_{3}+0,000015 X_{4}$ 
Tabel 1. Hasil Uji Regresi Linier Berganda

\begin{tabular}{|c|c|c|c|c|c|c|c|c|}
\hline \multirow{2}{*}{\multicolumn{2}{|c|}{ Model }} & \multicolumn{2}{|c|}{$\begin{array}{c}\text { Unstandardized } \\
\text { Coefficients }\end{array}$} & \multirow{2}{*}{$\begin{array}{c}\begin{array}{c}\text { Standardi } \\
\text { zed } \\
\text { Coefficie } \\
\text { nts }\end{array} \\
\text { Beta }\end{array}$} & \multirow[b]{2}{*}{$t$} & \multirow[b]{2}{*}{ Sig. } & \multicolumn{2}{|c|}{$\begin{array}{l}\text { Collinearity } \\
\text { Statistics }\end{array}$} \\
\hline & & B & $\begin{array}{l}\text { Std. } \\
\text { Error }\end{array}$ & & & & $\begin{array}{c}\text { Tolera } \\
\text { nce }\end{array}$ & VIF \\
\hline \multirow[t]{5}{*}{1} & (Constant) & 1005.463 & 337.420 & & 2.980 & .014 & & \\
\hline & Harga lahan & .478 & .199 & .291 & 2.399 & .037 & .117 & 8.520 \\
\hline & Kepadatan penduduk & .342 & .064 & .359 & 5.345 & .000 & .383 & 2.610 \\
\hline & Produktivitas (X3) & -97.598 & 36.102 & -.293 & -2.703 & .022 & .147 & 6.806 \\
\hline & PDRB & .000015 & .000 & .138 & 1.315 & .218 & .157 & 6.358 \\
\hline
\end{tabular}

a. Dependent Variable: Alih Fungsi Lahan (Y)

Berdasarkan koefisien regresi dari masing-masing variabel bebas pada persamaan regresi diatas, maka dapat dijelaskan sebagai berikut :

a. Jika faktor-faktor lain pada variabel-variabel independent dianggap konstan (X - 0) maka nilai alih fungsi lahan sawah adalah sebesar 1005,463 Ha.

b. Apabila koefisien regresi variabel harga lahan meningkat sebesar satu-satuan atau satu tingkat, maka akan terjadi peningkatan alih fungsi lahan lahan sawah sebesar 0,478 Ha.

c. Apabila koefisien regresi variabel kepadatan penduduk meningkat sebesar satu-satuan atau satu tingkat, maka akan terjadi peningkatan alih fungsi lahan sawah sebesar 0,342 Ha.

d. Apabila koefisien regresi variabel produktivitas padi meningkat sebesar satusatuan atau satu tingkat, maka akan terjadi penurunan alih fungsi lahan sawah sebesar -97,598 Ha.

e. Apabila koefisien regresi variabel Jumlah PDRB meningkat sebesar satusatuan atau satu tingkat, maka akan terjadi peningkatan alih fungsi lahan sawah sebesar 0,000015 Ha.

\section{Uji Serempak ( Uji F)}

Uji F pada penelitian ini merupakan uji yang dilakukan untuk melihat apakah terjadi pengaruh nyata antara peubah independent terhadap dependent secara keseluruhan. Uji F diketahui dengan melihat signifikan F hitung apakah lebih besar dari alpha yang ditetapkan $(0,05)$ atau tidak. Untuk melihat besarnya pengaruh secara keseluruhan terhadap variabel yang akan diteliti maka dapat dilihat pada Tabel 2.

Berdasarkan hasil Uji F ( secara simultan) diperoleh $F_{\text {hitung }}$ sebesar 141,973 sedangkan $F_{\text {tabel }}$ pada tingkat signifikansi $\alpha=5 \%$ adalah sebesar 3,36. Hal ini menunjukkan bahwa $F_{\text {hitung }}>F_{\text {tabel }}(141,973>3,36)$ dengan tingkat signifikansi 0,000. Dari hasil perhitungan ini dapat diambil suatu kesimpulan bahwa menerima $\mathrm{Ha}$ dan menolak Ho, artinya bahwa varibel Harga Lahan, Kepadatan Penduduk, Produktivitas Padi dan Jumlah PDRB secara bersama-sama atau simultan berpengaruh secara signifikan terhadap alih fungsi lahan sawah di Kabupaten Aceh Besar. 
Tabel 2. Hasil Uji F

\begin{tabular}{|ll|r|r|r|r|r|}
\hline \multicolumn{1}{|l|}{} & \multicolumn{1}{c|}{ Sum of } & & & & \\
\hline 1 & Squares & df & Mean Square & $\mathrm{F}$ & Sig. \\
\hline & Regression & 1482180 & 4 & 370545.016 & 141.973 & $.000^{\mathrm{a}}$ \\
& Residual & 26099.67 & 10 & 2609.967 & & \\
& Total & 1508280 & 14 & & & \\
\hline
\end{tabular}

a. Predictors: (Constant), PDRB, Kepadatan penduduk, Produktivitas (X3), Harga lahan

b. Dependent Variable: Alih Fungsi Lahan (Y)

\section{Uji Parsial (Uji t)}

Uji t pada penelitian ini bertujuan untuk mengetahui pengaruh masing-masing variabel bebas terhadap variabel tak bebas. Pengujian ini mempunyai tujuan untuk mengetahui apakah koefisien regresi signifikan atau tidak signifikan. Jika t hitung > dari pada $t$ Tabel, maka variabel bebas mempunyai pengaruh yang nyata terhadap variabel bebas, dengan kata lain terima Ha dan tolak Ho. Sebaliknya jika t hitung < dari pada $\mathrm{t}$ Tabel maka variabel bebas tidak mempunyai pengaruh yang nyata terhadap variabel terikat, dengan kata lain terima Ho dan tolak Ha. Adapun dapat kita lihat hasil uji t pada tabel berikut ini :

Tabel 3. Hasil Uji t

\begin{tabular}{|c|c|c|c|c|c|c|c|c|}
\hline \multirow{2}{*}{\multicolumn{2}{|c|}{ Model }} & \multicolumn{2}{|c|}{$\begin{array}{l}\text { Unstandardized } \\
\text { Coefficients }\end{array}$} & \multirow{2}{*}{$\begin{array}{c}\begin{array}{c}\text { Standardi } \\
\text { zed } \\
\text { Coefficie } \\
\text { nts }\end{array} \\
\text { Beta }\end{array}$} & \multirow[b]{2}{*}{$\mathrm{t}$} & \multirow[b]{2}{*}{ Sig. } & \multicolumn{2}{|c|}{$\begin{array}{l}\text { Collinearity } \\
\text { Statistics }\end{array}$} \\
\hline & & $\mathrm{B}$ & $\begin{array}{l}\text { Std. } \\
\text { Error }\end{array}$ & & & & $\begin{array}{c}\text { Tolera } \\
\text { nce }\end{array}$ & VIF \\
\hline \multirow[t]{5}{*}{1} & (Constant) & 1005.463 & 337.420 & & 2.980 & .014 & & \\
\hline & Harga lahan & .478 & .199 & .291 & 2.399 & .037 & .117 & 8.520 \\
\hline & Kepadatan penduduk & .342 & .064 & .359 & 5.345 & .000 & .383 & 2.610 \\
\hline & Produktivitas (X3) & -97.598 & 36.102 & -.293 & -2.703 & .022 & .147 & 6.806 \\
\hline & PDRB & .000015 & .000 & .138 & 1.315 & .218 & .157 & 6.358 \\
\hline
\end{tabular}

a. Dependent Variable: Alih Fungsi Lahan (Y)

\section{a. Pengaruh Harga Lahan Terhadap Alih Fungsi Lahan Sawah}

Secara parsial harga lahan berpengaruh positif terhadap alih fungsi lahan sawah. Hal ini ditunjukkan oleh koefisien regresi untuk variabel harga lahan sebesar 0,478. Hasil pengujian statistik menunjukkan nilai t hitung untuk harga lahan sebesar 2,399 dengan nilai signifikansi sebesar 0,037 . Sedangkan nilai t tabel sebesar 1,782. Karena nilai $t$ hitung > t tabel $(2,399>1,782)$. Dari hasil perhitungan ini menunjukkan bahwa variabel harga lahan berpengaruh nyata terhadap alih fungsi lahan sawah, karena semakin meningkat harga lahan maka akan semakin meningkat pula alih fungsi lahan sawah di Kabupaten Aceh Besar.

Merisa Kurniasari dan Putu Gde Ariastita (2014). Dalam penelitiannya yang berjudul "Faktor - Faktor yang Mempengaruhi Alih Fungsi Lahan Pertanian Sebagai Upaya Prediksi Perkembangan Lahan Pertaniandi Kabupaten Lamongan". Hasil penelitian menunjukkan bahwa Terdapat 2 variabel yang berpengaruh dalam mempengaruhi luasan alih fungsi lahan sawah di wilayah penelitian, yaitu rasio harga lahan (X2) dan rasio aksesibilitas wilayah (X4). Pada dua variabel yang signifikan mempengaruhi alih fungsi lahan sawah di kabupaten Lamongan menghasil kelompok- 
kelompok kecamatan yang mempunyai kesamaan karakteristik yang bisa mempengaruhi nilai penambahan luas alih fungsi lahan sawah di Kabupaten Lamongan.

\section{b. Pengaruh Kepadatan Penduduk Terhadap Alih Fungsi Lahan Sawah}

Secara parsial kepadatan penduduk berpengaruh positif terhadap alih fungsi lahan sawah. Hal ini ditunjukkan oleh koefisien regresi untuk variabel kepadatan penduduk sebesar 0,342. Hasil pengujian statistik menunjukkan nilai t hitung untuk kepadatan penduduk sebesar 5,345 dengan nilai signifikansi sebesar 0,000. Sedangkan nilai t tabel sebesar 1,782. Karena nilai t hitung > t tabel $(5,345>1,782)$ maka hipotesis Ha di terima dan sebaliknya hipotesis Ho ditolak yang berarti kepadatan penduduk berpengaruh signifikansi terhadap alih fungsi lahan sawah Artinya kepadatan penduduk mempengaruhi alih fungsi lahan sawah di Kabupaten Aceh Besar.

\section{c. Pengaruh Produktivitas Padi Terhadap Alih Fungsi Lahan Sawah}

Secara parsial produktivitas padi berpengaruh negatif terhadap alih fungsi lahan sawah. Hal ini ditunjukkan oleh koefisien regresi untuk variabel produktivitas padi sebesar -97,598. hasil pengujian statistik menunjukkan nilai t hitung untuk produktivitas padi sebesar 2,703 dengan nilai signifikan sebesar 0,022, sedangkan nilai t tabel sebesar 1,782. Karena nilai $\mathrm{t}$ hitung $>\mathrm{t}$ tabel $(2,703>1,782)$. Dari hasil perhitungan ini menunjukkan bahwa variabel produktivitas padi berpengaruh nyata terhadap alih fungsi lahan sawah, karena semakin banyak hasil produktivitas padi yang dihasilkan oleh petani maka akan semakin meningkat alih fungsi lahan sawah di Kabupaten Aceh Besar.

\section{d. Pengaruh Jumlah PDRB Terhadap Alih Fungsi Lahan Sawah}

Secara parsial Jumlah PDRB berpengaruh positif terhadap alih fungsi lahan sawah. Hal ini ditunjukkan oleh koefisien regresi untuk variabel jumlah PDRB sebesar 0,00015. Hasil pengujian statistik menunjukkan nilai t hitung untuk jumlah PDRB sebesar 1,315 dengan nilai signifikan sebesar 0,218. Sedangkan nilai t tabel sebesar 1,782. Karena nilai $\mathrm{t}$ hitung $<\mathrm{t}$ tabel $(1,315<1,782)$. Dari hasil perhitungan ini menunjukkan bahwa variabel jumlah PDRB tidak berpengaruh nyata terhadap alih fungsi lahan sawah, karena semakin tinggi jumlah PDRB yang dihasilkan maka akan semakin menurun alih fungsi lahan sawah di Kabupaten Aceh Besar.

Zaenil Mustopa (2011), dalam penelitiannya yang berjudul "Analisis FaktorFaktor Yang Mempengaruhi Alih Fungsi Lahan Pertanian Di Kabupaten Demak". Hasil penelitian menunjukkan bahwa secara keseluruhan baik itu jumlah penduduk, jumlah industri, maupun jumlah PDRB berpengaruh positif terhadap besarnya alih fungsi lahan. Akan tetapi hanya variabel jumlah penduduk dan jumlah industri yang terbukti signifikan. Variabel jumlah PDRB terbukti tidak signifikan.

\section{KESIMPULAN DAN SARAN}

Berdasarkan hasil penelitian dan pembahasan serta pengujian SPSS menunjukkan bahwa harga lahan, kepadatan penduduk, dan produktivitas padi berpengaruh nyata terhadap alih fungsi lahan sawah di Kabupaten Aceh Besar. Hasil statistik menunjukkan nilai t hitung untuk harga lahan sebesar 2,399 dan nilai t tabel sebesar 1,782 yang berarti nilai t hitung $>\mathrm{t}$ tabel $(2,399>1,782)$, nilai t hitung untuk kepadatan penduduk sebesar 5,345 dan nilai t tabel sebesar 1,782 yang berarti thitung >t tabel $(5,345>1,782)$, nilai t hitung untuk produktivitas padi sebesar 2,703 dan nilai t tabel sebesar 1,782 yang berarti nilai $\mathrm{t}$ hitung $>\mathrm{t}$ tabel $(2,703>1,782)$ sedangkan jumlah PDRB tidak berpengaruh terhadap alih fungsi lahan sawah. Hal ini ditunjukkan oleh koefisien regresi untuk variabel jumlah PDRB sebesar 0,00015. Hasil pengujian statistik menunjukkan nilai t hitung untuk jumlah PDRB sebesar 1,315 dengan nilai signifikan sebesar 0,218. 
Sedangkan nilai t tabel sebesar 1,782 yang berarti nilai $t$ hitung $<\mathrm{t}$ tabel $(1,315<1,782)$. Dari hasil perhitungan ini menunjukkan bahwa variabel jumlah PDRB tidak berpengaruh nyata terhadap alih fungsi lahan sawah.

Adapun saran yang dapat diberikan adalah sebagai berikut : Adapun saran yang dapat diberikan adalah sebagai berikut : Bagi peneliti selanjutnya diharapkan agar dapat melakukan penelitian lebih lanjut terkait faktor-faktor lain diluar penelitian ini yang menyangkut alih fungsi lahan baik berpengaruh maupun tidak berpengaruh secara nyata.

\section{DAFTAR PUSTAKA}

Anugerah, F. 2005. Analisis Faktor-Faktor Yang Mempengaruhi Konversi Lahan Sawah Ke Penggunaan Non Pertanian di Kabupaten Tangerang. Skripsi. Fakultas Pertanian Institute Pertanian Bogor.

Asmara, A. 2011. Pendapatan petani setelah konversi lahan (studi kasus di kelurahan Mekarwangi Kota Bogor).

Barokah, U., Supardi, S., \& Handayani, S. M. (2012). Dampak Konversi Lahan Pertanian Terhadap Pendapatan Rumah Tangga Petani di Kabupaten Karanganyar. Caraka Tani-Jurnal Ilmu Ilmu Pertanian, 27(1), 93-99.

Bambang Irawan, Juli 2005. Konversi Lahan Sawah: Potensi Dampak, Pola Pemanfaatan, dan Faktor Determinan. dalam Jurnal forum Penelitian Agro ekonomi Volume 23.

Dewi dan Sarjana. 2015. Faktor-Faktor Pendorong Alih Fungsi Lahan Menjadi Lahan Non Pertanian. Program Studi Agribisnis Fakultas Pertanian Universitas Udayana, Bali, Indonesia.

Dinaryanti, N. (2014). Faktor-Faktor Yang Mempengaruhi Alih Fungsi Lahan Pertanian Di Daerah Sepanjang Irigasi Bendung Colo Kabupaten Sukoharjo (Doctoral dissertation, Fakultas Ekonomika dan Bisnis).

Fanny, A. 2005. "Analisis Faktor-Faktor Yang Mempengaruhi Konversi Lahan Sawah Ke Penggunaan Non Pertanian Di Kabupaten Tangerang”. Skripsi. Fakultas Pertanian Institute Petanian Bogor.

Ghozali, Imam. 2009. " Aplikasi Analisis Multivariate dengan Program SPSS". Semarang : UNDIP.

Gujarati D. 2002. Basic Economics. Mc Graw Hill, Singapore.

Hidayati, H. N. (2013). Konversi Lahan Sawah dan Sikap Petani di Desa Cihideung Ilir Kabupaten Bogor [Skripsi]. Bogor (ID): Institut Pertanian Bogor.

Ilham, N., Syaukat, Y., Friyatno, S. 2008. "Perkembangan dan Faktor-Faktor Yang Mempengaruhi Konversi Lahan Sawah Serta Dampak Ekonominya”. Bogor. Pusat Penelitian dan Pengembangan Sosial Ekonomi Pertanian Bogor.

Ilham, dkk. 2003. Perkembangan Dan Faktor-Faktor Yang Mempengaruhi Konversi Lahan Sawah Serta Dampak Ekonominya. IPB Press. Bogor.

Irawan, B dan S. Friyatno. 2001. Dampak Konversi Lahan Sawah di Jawa terh adap Produksi Beras dan Kebijakan Pengendaliannya . Jurnal Sosial Ekonomi Pertanian dan Agribisnis SOCA : Vol.2 No.2 : 79- 95. Fakultas Pertanian Universitas Udayana, Denpasar.

Irawan, B. 2005. "Konversi Lahan Sawah: Potensi Dampak, Pola Pemanfaatannya, dan Faktor Determinan”. Bogor. Pusat Peneitian dan Pengembangan Sosial Ekonomi Pertanian Bogor. 
Kurniasari, M dan P.G. Ariastita. 2014. Faktor-Faktor Yang Mempengaruhi Alih Fungsi Lahan Pertanian Sebagai Upaya Prediksi Perkembangan Lahan Pertanian Di Kabupaten Lamongan . Jurnal Teknik POMITS Vol. 3, No. 2

Lestari, T.2009. Dampak Konversi Lahan Pertanian Bagi Taraf Hidup Petani. IPB. Bogor.

Lestari, T. 2005. Pengaruh Variabel Makro Terhadap Return Saham di Bursa Efek Jakarta : Pendekatan Beberapa Model . SNA VII Solo. 